\title{
Isolation, Characterization and Identification of Lactic Acid Bacteria as Probiotic
}

\author{
El-Beksh, Amany E.; Abou-Aly, H.E.*; Zaghloul, R.E. ; El-Meihy, Rasha M. \\ Agricultural Microbiology Department, Faculty of Agriculture, Benha University, Moshtohor, Qaluybia, P. O. \\ 13736, Egypt. \\ *Corresponding author: haboualy@fagr.bu.edu.eg
}

\begin{abstract}
Lactic acid bacteria that grow as the adventitious microflora of foods or that are added to foods as cultures are generally considered to be harmless or even an advantage for human health. The objective of this study was to isolate, screen and identify lactic acid bacteria from different sources. As well, evaluate the more potent lactic acid bacteria isolates for their probiotic characteristics. Ninety-six bacterial isolates were isolated from different 18 sources, 51 (53\%) isolates were able to hydrolyze $0.5 \%$ bile salts while 28 isolates were able to hydrolyze $1 \%$ bile salts. Also, only 11 isolates were able to tolerate $2 \%$ bile salts after $6 \mathrm{~h}$ incubation periods. On the other hand, lactic acid bacteria isolates were able to survive at $\mathrm{pH} 1.5$ and 3.0 as well 8.0. Also, these isolates were potent for cholesterol assimilation, $\mathrm{NaCl}$ tolerance, exopolysaccharides production, antioxidant activity. Lactic acid bacteria isolate MS87 that exhibited excellent probiotic characteristics was identified using 16S rRNA sequence as Pediococcus pentosaceus. This study led to suggest that environmental-derived lactic acid bacteria-strains could be used as a potential source of probiotic.
\end{abstract}

Keywords: Lactic acid bacteria, probiotics, bile salts tolerance, antibiotic sensitivity, cholesterol assimilation.

\section{Introduction}

Lactic acid bacteria (LAB) have been exploited for centuries as probiotics to promote good human and animal health (Bhattacharyya, 2009). They play important role in food fermentation, primarily by causing the characteristic flavor changes and contributing a preservative effect on the fermented product. These bacteria are widely used as starter cultures in most fermented foods such as dairy products (Antara et al., 2009). However, some strains of LAB could be used as probiotic (Verdenelli et al., 2009).

LAB used for centuries by man to preserve food, produce antagonistic compounds, including lactic acid, hydrogen peroxide and bacteriocins. Bacteriocins are antimicrobial peptides that are bactericidal toward bacteria taxonomically close to the producer. The specific actions of some bacteriocins toward foodborne pathogenic bacteria and undesirable flora like Listeria spp. and Clostridium spp. have increased the interest in these compounds (Daba and Saidi, 2015). LAB are safe microorganisms with abilities to produce different inhibitory compounds such as bacteriocins, organic acids, hydrogen peroxide, diacetyl and carbon dioxide. $\mathrm{LAB}$ can inhibit harmful microorganisms through competitive exclusion mechanism based on competition for binding sites and nutrients (ViecoSaiz et al., 2019).

Probiotics are live non-pathogenic microorganisms which give benefits to human and animal health, such as induction of the immune system (Hirayama and Rafter, 2000), prevention of pathogens infection and colonization in the gastrointestinal system (Lawrence $\boldsymbol{e t}$ al., 2005) and modulation of the blood cholesterol level (Martin $\boldsymbol{e t}$ al., 2008). Several LAB have been used as probiotics in humans and animals (Morelli, 2000). The probiotics criteria include the biosafety of the strains, ability to adhere to and colonize the epithelial cell surface of the gastrointestinal tract of the host and inhibitory activity against enteric pathogens (Collins et al., 1998). The acid and bile tolerance as well are two fundamental properties that indicate the ability of probiotic microorganism for survival during passage through the gastrointestinal tract (Erkkila and Petaja, 2000). Somashekaraiah et al. (2019) reported that $\mathrm{LAB}$ exhibited promising probiotic properties and seem favorable for use in functional fermented foods as preservatives. The aim of this study was to isolate, screen and identify LAB from different sources as well as evaluate the more potent probiotic $\mathrm{LAB}$ isolates for their probiotic characteristics.

\section{Materials and methods}

\section{Collection of samples}

Different fresh and preserved food products were collected from local markets in Qaluyobia Governorate, Egypt namely: milk (fresh, Nedo and Hero), rayeb (Johyena and Almarai); yogurt ( Balady, Johyena, Danon, Lactel, Healthy, Activia, Nestle); ice cream; Salamy; Boza, Keshk, Serelak and baby feces during 2017. Samples were aseptically transported to the laboratory of Agric. Microbiology Dept., Fac. of Agric., Benha University.

\section{Enrichment and isolation of LAB}

Five grams of each sample was mixed with $100 \mathrm{ml}$ of de Man Rogosa Sharp (MRS) broth medium (de Man et al., 1960) which containing (g/l): 10.0 proteose peptone No.3,10.0 beef extract, 5.0 yeast extract, 20.0 dextrose, 1.0 polysorbate $80,2.0$ ammonium citrate, 5.0 sodium acetate, 0.1 
magnesium sulfate, 0.05 manganese sulfate, 2.0 dipotassium phosphate, 20.0 agar. Then, incubated at $37^{\circ} \mathrm{C}$ for $48 \mathrm{~h}$. After that, $1.0 \mathrm{ml}$ of each mixture was diluted to $10^{7}$, then $0.1 \mathrm{ml}$ of the suitable dilutions were spread onto the surface of MRS agar medium (Jimenez et al., 2008). After incubation at $37^{\circ} \mathrm{C}$, colonies with different morphologies were collected and purified on the same medium and stored at $4{ }^{\circ} \mathrm{C}$.

\section{Survival under gastrointestinal tract conditions Bile salt hydrolase activity}

Two methods were used for determination of bile salts hydrolase activity. The first method by Toit $\boldsymbol{e t}$ al . (2003) was as follows: 24 h old bacterial cultures were streaked on MRS agar supplemented with $0.5 \%$ w/v bile salts (Ox Bile, HIMEDIA, India) and incubated for $48 \mathrm{~h}$ at $37^{\circ} \mathrm{C}$. The hydrolysis effect was evaluated by partial hydrolysis in comparison to the control MRS dishes and recorded as + and - for positive and negative results.

The second method described by Sedláčkovám et al. (2015) was as follows: soft MRS agar ( $\mathrm{pH}$ 5.6), bile salts $(1.0 \% \mathrm{w} / \mathrm{v})$, and $\mathrm{CaCl}_{2}(0.375 \mathrm{~g} / \mathrm{l})$, was used. Petri dishes were incubated at $37^{\circ} \mathrm{C}$ for $48 \mathrm{~h} .10 \mu \mathrm{l}$ of each isolate were inoculated on MRS soft agar by puncturing into the agar. Subsequent cultivation of the MRS agar media containing bacterial isolates was carried out at $37^{\circ} \mathrm{C}$ for $72 \mathrm{~h}$. Visible halos indicate the positive bile salt hydrolase activity of the isolates.

\section{Bile salt tolerance}

The method of Oloyede and Afolabi (2013) was used to determine bile salt tolerance. MRS broth containing $0, \quad 1.5$ and $2.0 \%(\mathrm{w} / \mathrm{v})$ bile salts (HIMEDIA, India) was inoculated with $10^{7} \mathrm{cfu} / \mathrm{ml}$ of each $\mathrm{LAB}$ isolate from their respective overnight growth culture after they were centrifuged at $10000 \mathrm{~g}$ for $5 \mathrm{~min}$. and washed three times, then incubated for different intervals viz. $0,2,4$ and $6 \mathrm{~h}$ at $37^{\circ} \mathrm{C}$. One $\mathrm{ml}$ of each isolate was diluted to $10^{-7}$ and the number of cells were counted using pour plate method for resistance to bile salts. Survival rate $(\%)=\log \mathrm{cfu} / \mathrm{ml}$ of treatment / $\log \mathrm{cfu} / \mathrm{ml}$ of control $\times 100$.

\section{Acid tolerance}

The modified method of Erkkila and Petaja (2000) was applied in this study. Bacterial isolates grown in MRS broth at $37^{\circ} \mathrm{C}$ for $24 \mathrm{~h}$. were collected by centrifugation at $5000 \times \mathrm{g}$ for $15 \mathrm{~min}$. Cell pellet was washed twice and resuspended into $10 \mathrm{ml}$ of phosphate-buffered saline (PBS) with the $\mathrm{pH}$ values $1.5,3.0$ and 8.0 (adjusted using $5 \mathrm{M} \mathrm{HCl}$ ) to achieve $10^{3} \mathrm{CFU} / \mathrm{ml}$. The tubes were incubated at $37^{\circ} \mathrm{C}$ and the viable cells were counted after exposure to acidic condition for 2, 3, 4 and $5 \mathrm{~h}$. on MRS agar incubated at $37^{\circ} \mathrm{C}$ for $48 \mathrm{~h}$. Survival rate $(\%)=\log \mathrm{cfu} / \mathrm{ml}$ of treatment / $\log \mathrm{cfu} / \mathrm{ml}$ of control $\times 100$.

\section{Preliminary identification of isolates}

Phenotypic characteristics (morphological, physiological and biochemical tests) were performed to identify the most potent isolates according to criteria of Bergy's Manual of Determinative Bacteriology. Shape, motility, Gram staining, catalase activity, growth at different temperature and $\mathrm{pH}$, salt tolerance, sugar fermentation, citrate utilization, $\mathrm{H}_{2} \mathrm{~S}$ production, VR test, MR test, oxidase test and urease test were determined according to (Holt et al., 1994).

\section{Probiotic characterizations \\ NaCl tolerance}

For determination of $\mathrm{NaCl}$ tolerance of all tested isolates, four test tubes containing MRS broth were adjusted with different concentration (1.5-3-5-7\%) of $\mathrm{NaCl}$ for each isolate with three replicates. After sterilization, MRS medium was inoculated individually with $1 \%(\mathrm{v} / \mathrm{v})$ overnight culture $\left(10^{7}\right.$ $\mathrm{cfu} / \mathrm{ml}$ ) and incubated at $37^{\circ} \mathrm{C}$ for $24 \mathrm{~h}$. After that, the growth was determined by observing culture medium turbidity and recorded as slightly $(+)$, moderately $(++)$ and heavy growth (+++) (Hoque et al., 2010).

\section{Antioxidant activity \\ Preparation of cell free extract}

MRS broth medium ( $\mathrm{pH} 6.5 \pm 0.2$ ) was individually inoculated with $1 \%(\mathrm{v} / \mathrm{v})$ of the over-night grown cultures and incubated at $37^{\circ} \mathrm{C} \pm 0.2$ for $24 \mathrm{~h}$ in shaking incubator $(150 \mathrm{rpm})$. Cell free extract (CFE) was obtained by centrifugation at 10,000 rpm for $5 \mathrm{~min}$ at $4^{\circ} \mathrm{C}$ and kept at $4^{\circ} \mathrm{C}$ for non-enzymatic antioxidant assay.

\section{DPPH free radical scavenging assay}

2,2-DiPhenyl-2-Picryl hydrazyl hydrate (DPPH) free radical scavenging assay was measured as nonenzymatic assay using the method described by Heo et al. (2006). $500 \mu \mathrm{L}$ of CFE, $3000 \mu \mathrm{l}$ of a freshly prepared solution of DPPH at a concentration of 5 $\mathrm{mg} / 100 \mathrm{ml}$ ethanol was added. Control was prepared using $500 \mu \mathrm{l}$ of ethanol added to $3000 \mu \mathrm{L} \mathrm{DPPH}$ solution, mixed and incubated for $30 \mathrm{~min}$. in dark. Absorbance (As) was measured at $517 \mathrm{~nm}$ after 30 min. Ascorbic acid was used as a standard. The percentage of radical scavenging activity was calculated according to the following equations:

$$
\begin{aligned}
& \% \text { Residual of DPPH after } 30 \mathrm{~min} \\
& =\frac{\text { As517 control-As517 sample }}{\text { As517 control }} \times 100 \\
& \begin{array}{r}
\% \text { Inhibited of DPPH after } 30 \mathrm{~min} \\
=\% \text { Residual of DPPH } \\
-100
\end{array}
\end{aligned}
$$

\section{Hemolytic activity}

For hemolytic activity, the overnight grown MRS broth culture of each isolate was streaked on blood agar plate (Hi-Media, India) and incubated at $37^{\circ} \mathrm{C}$ for $48 \mathrm{~h}$; after that, all plates were checked for the formation of any hemolytic zones viz. clear $(\beta-$ 
hemolysis) or greenish ( $\alpha$-hemolysis), or no hemolytic zone ( $\lambda$-hemolysis) (Borah et al., 2016).

\section{Antibiotic susceptibility assay}

Antibiotic resistance/susceptibility of all isolates were estimated by disc diffusion method as described by Kacem and Karam (2006). Seven antibiotics viz. penicillin $\mathrm{G}(10 \mu \mathrm{g})$, neomycin $(10 \mu \mathrm{g})$, tetracycline $(30 \mu \mathrm{g})$, erythromycin $(15 \mu \mathrm{g})$, chloramphenicol $(30 \mu \mathrm{g})$, vancomycin $(30 \mu \mathrm{g})$ and gentamycin $(10 \mu \mathrm{g})$ were used in this experiment. MRS medium was individually inoculated with $200 \mu \mathrm{l}$ of $24 \mathrm{~h}$ old cultures $\left(10^{7} \mathrm{cfu} / \mathrm{ml}\right)$ and allowed to stand at room temperature for $15 \mathrm{~min}$ and then the antibiotic discs were dispensed onto agar using disc dispenser under aseptic conditions, then incubated at $37^{\circ} \mathrm{C}$ for $24 \mathrm{~h}$. Inhibition zone was measured $(\mathrm{mm})$. Results were expressed as sensitive (S) or resistant (R) according to Oloyede and Afolabi (2013).

\section{Cholesterol assimilation}

Cholesterol assimilation was done by the method described by Searcy and Bergusst (1960) as follows: bacterial isolates were grown in MRS broth supplemented with $0.3 \%$ bile salt (sodium thioglycolate, SRL). Further, $0.1 \mathrm{~g}$ of cholesterol dissolved in $2.5 \mathrm{~mL}$ of ethanol was added to $10 \mathrm{~mL}$ of MRS broth with bile salt. The cultures were grown for $24 \mathrm{~h}$ at $37^{\circ} \mathrm{C}$. Cells were harvested by centrifugation at $8000 \times \mathrm{g}$ for $10 \mathrm{~min}$. Supernatant was collected and used for cholesterol assay. The uninoculated MRS broth was considered as a control. The concentration of cholesterol was determined using cholesterol standard graph as described by Tomaro-Duchesneau et al. (2014). A standard curve of absorbance versus cholesterol concentrations was generated using the cholesterol concentrations: $0,3.91,7.81,15.63,31.25$, $62.5,125,250$, and $500 \mu \mathrm{g} / \mathrm{mL}$ cholesterol in MRS $\left(R^{2}\right.$ $=0.9928)$. The cholesterol assimilated by LAB isolates was determined using the following equations:

Cholesterol assimilated $(\mu \mathrm{g} / \mathrm{ml})$

$\%$ cholesterol assimilated

$$
=[\text { cholesterol }(\mu \mathrm{g} / \mathrm{ml})] 0 \mathrm{~h}
$$$$
-[\text { cholesterol }(\mu \mathrm{g} / \mathrm{ml})] 24 \mathrm{~h}
$$

$=\frac{\text { cholesterol assimilated }(\mu \mathrm{g} / \mathrm{ml})}{\text { cholesterol }(\mu \mathrm{g} / \mathrm{ml}) 0 \mathrm{~h}} \times 100 \%$

\section{Genotypic identification of the potent probiotic isolates}

The most potent isolates were completely identified using $16 \mathrm{~S}$ rRNA sequence technique. The isolates were grown in MRS broth on a rotary shaker $(120 \mathrm{rpm})$ at $30^{\circ} \mathrm{C}$ for 24 hours. Bacterial Gene Jet genomic DNA purification Kit (Thermo K0721) was used to extract DNA according to SIGMA company instructions. The universal $16 \mathrm{~S}$ primers used were; forward primer: AGAGTT TGATCCTGGCTCAG and reverse primer: GGT TACCTTGTTACGACT T. The sequencing was performed in two direction using the previously described primers (Doi $\boldsymbol{e t}$ al., 2013).

\section{Results and discussion}

\section{Isolation of $\mathbf{L A B}$}

Totally of 96 bacterial isolates were isolated from different sources and coded as MS (1-96). The largest number (12 isolates) were obtained from fresh milk, while the lowest number ( 2 isolates) obtained from Rayeb milk (Almarai) and yoghurt (Johyena). Same trend of results was recorded by Weese et al. (2004) who reported that $\mathrm{LAB}$ have adapted to grow under widely different environmental conditions, and they are widespread in nature. Apart from food sources, LAB are commonly found in the gastrointestinal tract of various animals and humans (Tannock, 1995). Also, Oloyede and Afolabi (2013) isolated fifty LAB isolates from goat milks.

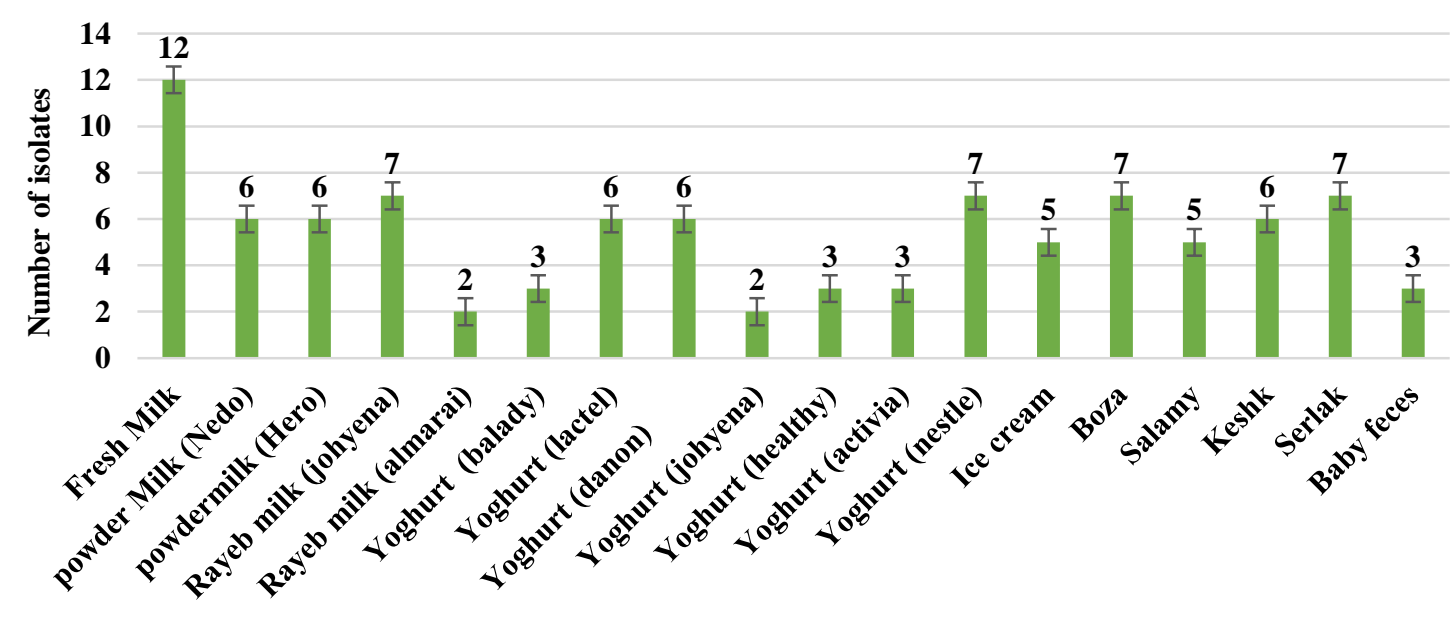

\section{Source of isolates}

Fig. 1. Number of bacterial isolates from different sources 
Survival under GIT conditions

Bile salts hydrolase activity

The ability of the isolated bacteria to hydrolase bile salts was done in two successive steps. In the first step, 51 of $96(53 \%)$ isolates were able to hydrolase $0.5 \%$ bile salts while 45 isolates $(47 \%)$ were not able to hydrolase bile salts at the same concentration (Fig 2). On the other hand, the isolates which gave positive results in the first step were examined in the second step for hydrolase $1.0 \%$ bile salts. Results in Table (1) and Fig (2) indicated that only 28 from 51 isolates
(55\%) were able to hydrolase $1 \%$ bile salts while, 23 isolates $(45 \%)$ don't have this ability. The halo zone of hydrolysis was ranged from 1.0 to $5.5 \mathrm{~cm}$. The highest zone was recorded by the isolate MS13 while, the lowest zone was recorded by the isolates MS47, MS55, MS68 and MS84. The bile salt hydrolase, which described in several $\mathrm{LAB}$ as probiotic organisms, are produced in the intracellular space. (Negm El-Dein, et al., 2017).
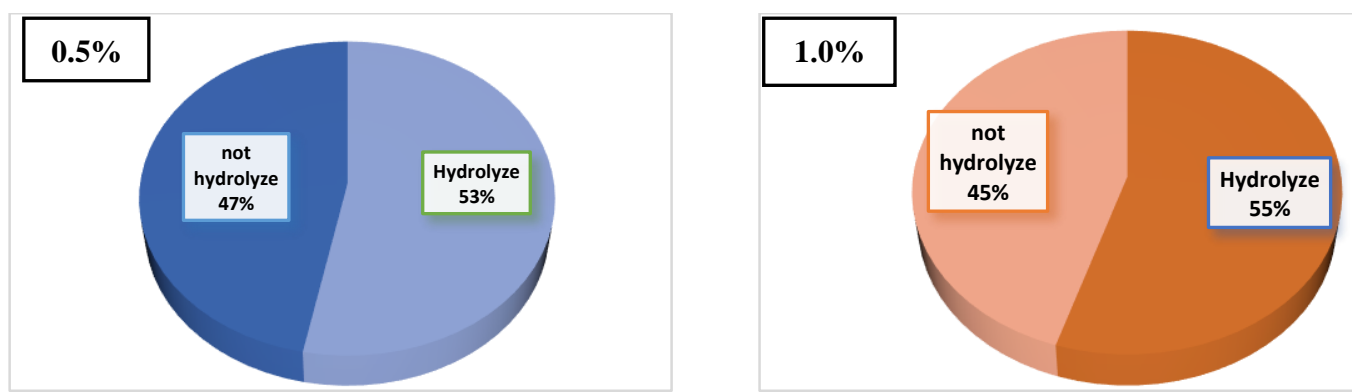

Fig. 2. Bile salts hydrolysis by bacterial isolates

Table 1. Bile salt hydrolase activity at $1 \%$.

\begin{tabular}{cc}
\hline $\begin{array}{c}\text { Zone }(\mathbf{m m}) \text { of bile salt hydrolase } \\
\text { activity }\end{array}$ & LAB isolates \\
\hline$<\mathbf{1 . 0}$ & MS $(5,9,10,14,16,20,21,32,35,39,40,41,43,45,51,56,58$, \\
$\mathbf{1 . 0}-\mathbf{2 . 5}$ & $69,73,74,91,92,93)$ \\
$\mathbf{2 . 6}-\mathbf{4 . 0}$ & MS $(47,24,25,37,46,47,54,55,60,62,64,65,68,90)$ \\
$\mathbf{4 . 0}-\mathbf{5 . 5}$ & MS $(8,18,57,67)$ \\
$>\mathbf{5 . 5}$ & MS $(12,13,19,44,84,71,85,86)$ \\
& MS87, MS88 \\
\hline
\end{tabular}

Bile salts tolerance

In this experiment two consecutive steps were done, the first was designed to examine the ability of LAB to tolerate $1.5 \%$ bile salts while, the second step was to examine the ability of $1.5 \%$ bile salt tolerated isolates to tolerate $2.0 \%$ bile salts. Regarding the ability of the isolates to tolerate $1.5 \%$ bile salts, data presented in Table (2) indicated that the number of the viable cells were decreased with the increasing of the incubation period. Generally, the lowest number of viable cells of all isolates was recorded after 6 hours of incubation.

Table 2. Tolerance of the isolated bacteria for $1.5 \%$ bile salt.

\begin{tabular}{|c|c|c|c|c|c|c|c|c|c|}
\hline \multirow{2}{*}{$\begin{array}{c}\text { LAB } \\
\text { isolates }\end{array}$} & \multicolumn{4}{|c|}{ Survival rate $(\%)$ after incubation $(h)}$. & \multirow{2}{*}{$\begin{array}{c}\text { LAB } \\
\text { isolates }\end{array}$} & \multicolumn{4}{|c|}{$\begin{array}{l}\text { Survival rate (\%) after incubation (h.) } \\
\text { Sulon }\end{array}$} \\
\hline & Zero time & 2 & 4 & 6 & & Zero time & 2 & 4 & 6 \\
\hline MS 8 & 99.58 & 98.19 & 97.39 & 97.10 & MS 57 & 92.79 & 0.0 & 0.0 & 0.0 \\
\hline MS 12 & 99.85 & 99.59 & 99.59 & 99.05 & MS 60 & 96.48 & 93.63 & 0.0 & 0.0 \\
\hline MS 13 & 99.91 & 98.48 & 98.03 & 95.66 & MS 62 & 99.16 & 99.89 & 99.47 & 99.05 \\
\hline MS 17 & 99.96 & 0.0 & 0.0 & 0.0 & MS 64 & 99.41 & 98.21 & 98.21 & 98.21 \\
\hline MS 18 & 99.81 & 99.34 & 98.45 & 97.93 & MS 65 & 99.88 & 99.80 & 98.67 & 98.28 \\
\hline MS 19 & 100.0 & 99.97 & 97.93 & 95.23 & MS 67 & 99.57 & 99.57 & 99.55 & 99.64 \\
\hline MS 24 & 99.92 & 99.28 & 98.84 & 97.51 & MS 68 & 88.97 & 0.0 & 0.0 & 0.0 \\
\hline MS 25 & 99.84 & 99.55 & 99.30 & 98.45 & MS 71 & 99.77 & 99.46 & 98.96 & 96.77 \\
\hline MS 37 & 99.95 & 99.05 & 94.19 & 92.64 & MS 84 & 99.14 & 99.05 & 98.63 & 97.62 \\
\hline MS 44 & 99.95 & 99.45 & 99.06 & 98.23 & MS 85 & 100.0 & 98.42 & 97.45 & 96.22 \\
\hline MS 46 & 99.88 & 99.52 & 98.75 & 98.32 & MS 86 & 99.98 & 98.92 & 98.72 & 97.82 \\
\hline MS 47 & 99.79 & 99.69 & 99.53 & 99.40 & MS 87 & 99.83 & 99.34 & 99.00 & 98.08 \\
\hline MS 54 & 99.15 & 99.31 & 99.15 & 98.98 & MS 88 & 98.86 & 98.51 & 98.42 & 98.18 \\
\hline MS 55 & 99.70 & 99.11 & 90.09 & 0.0 & MS 90 & 100.0 & 99.49 & 97.53 & 94.19 \\
\hline
\end{tabular}


Also, the isolates MS17, MS57 and MS68 didn't able to survive at $1.5 \%$ bile salts more than 2 hours. Additionally, the highest survival rate after $6 \mathrm{~h}$. of incubation was recorded by the isolate MS12 followed by the isolate MS54. Similar results were showed by Fungsin et al. (2010) who proved that the number of survival strains at $4 \mathrm{~h}$. had relatively high tolerance to bile salts up to $1.5 \%(\mathrm{w} / \mathrm{v})$.

Concerning the ability of the isolates to tolerate $2 \%$ bile salts, data in Table (3) showed that only 11 isolates were able to tolerate $2 \%$ bile salts after
$6 \mathrm{~h}$ incubation periods. Moreover, 6 isolates didn't able to tolerate $2 \%$ bile salts at zero time. On the other hand, the highest values of survival rate were recorded by the isolate no. MS88 followed by MS24 then MS19. Generally, survival rate was decreased with the increasing of the incubation period. The selected 11 isolates were chosen to the further experiments. Bile salt tolerance is one of the prerequisites for any species of LAB when it is used as probiotics (Badi and Bhat, 2017).

Table 3. Tolerance of bacterial isolates for $2.0 \%$ bile salt.

\begin{tabular}{|c|c|c|c|c|c|c|c|c|c|}
\hline \multirow{2}{*}{ 势 } & \multicolumn{4}{|c|}{$\begin{array}{c}\text { Survival rate (\%) after incubation } \\
\text { (h.) }\end{array}$} & \multirow{2}{*}{ 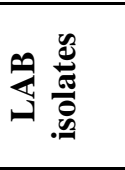 } & \multicolumn{4}{|c|}{ Survival rate (\%) after incubation (h.) } \\
\hline & $\begin{array}{l}\text { Zero } \\
\text { time }\end{array}$ & 2 & 4 & 6 & & $\begin{array}{l}\text { Zero } \\
\text { time }\end{array}$ & 2 & 4 & 6 \\
\hline MS 8 & 85.29 & 0.0 & 0.0 & 0.0 & MS 55 & 91.61 & $\begin{array}{l}90.39 \\
\end{array}$ & 0.0 & 0.0 \\
\hline MS 12 & 93.36 & 92.44 & 91.18 & 81.81 & MS 62 & 0.0 & 0.0 & 0.0 & 0.0 \\
\hline MS 13 & 97.81 & 95.36 & 88.84 & 85.20 & MS 64 & 0.0 & 0.0 & 0.0 & 0.0 \\
\hline MS 18 & 91.94 & 87.63 & 85.72 & 81.09 & MS 65 & 0.0 & 0.0 & 0.0 & 0.0 \\
\hline MS 19 & 91.35 & 92.27 & 92.94 & 86.78 & MS 67 & 0.0 & 0.0 & 0.0 & 0.0 \\
\hline MS 24 & 94.18 & 95.53 & 94.90 & 88.31 & MS 71 & 88.95 & 85.77 & 93.54 & 73.99 \\
\hline MS 25 & 0.0 & 0.0 & 0.0 & 0.0 & MS 84 & 88.39 & 86.93 & 80.83 & 75.67 \\
\hline MS 37 & 0.0 & 0.0 & 0.0 & 0.0 & MS 85 & 80.79 & 0.0 & 0.0 & 0.0 \\
\hline MS 44 & 86.69 & 81.57 & 81.57 & 81.57 & MS 86 & 91.12 & 90.64 & 88.16 & 81.56 \\
\hline MS 46 & 89.49 & 0.0 & 0.0 & 0.0 & MS 87 & 91.12 & 86.61 & 83.72 & 79.21 \\
\hline MS 47 & 89.44 & 85.82 & 77.92 & 74.70 & MS 88 & 97.68 & 95.24 & 96.07 & 88.87 \\
\hline MS 54 & 90.51 & 86.41 & 0.0 & 0.0 & MS 90 & 86.87 & 0.0 & 0.0 & 0.0 \\
\hline
\end{tabular}

\section{Tolerance of $\mathbf{p H}$ by bacterial isolates}

As probiotics are usually administered orally, they must have the ability to survive passage through the stomach and small intestine. Therefore, resistance to the low $\mathrm{pH}$ of the gastric juice in the stomach and the small intestine is one of the major important properties of probiotic bacteria (Yin and Zheng, 2005). Results of preliminary screening of $\mathrm{pH}$ tolerance presented in Table (4) showed that most of the isolates have the ability to survive at all tested $\mathrm{pH}$. At pH 1.5 only 20 isolates were able to survive after 5 h. while at the same time, 27 isolates and 24 isolates were able to survive at $\mathrm{pH} 3.0$ and 8.0, respectively. Twenty and twenty-eight strains were characterized for their ability to grow under acidic conditions to ensure their survival through the upper digestive tract to reach the large intestine when they were exposed to $\mathrm{pH} 1.5$ and3.0, respectively for 2,3 , and $5 \mathrm{~h}$. It is known that the resistance of probiotics to low $\mathrm{pH}$ greatly varies depending on the species and strain. In general, these results are in agreement with others researchers, who showed that species of lactic acid bacteria are high acid resistant at $\mathrm{pH} 2.0$ and 3.0 (The $\mathrm{pH}$ level of the gastric juice) and this resistance could be decreased on very low $\mathrm{pH}$ value (Chang et al., 2012). The $\mathrm{pH}$ of gastric juice can be increased in the presence of food components such as cheddar cheese and yoghurt (Gardiner et al., 1999).

This protective effect of food components to probiotic bacteria may facilitate the passage of acid- sensitive probiotic strains from the stomach into the small intestine. Resistance to low $\mathrm{pH}$ is one of the major selections for probiotic strains. LAB are indigenous habitants of human gastro intestinal tract and thought to among the dominant colonies of the small intestine. To reach the small intestine, they have to pass through stomach. For selection of strain resistant to low pH 3.0 was used. The time that takes during digestion in stomach is 3 hours, so isolates were tested for resistance to $\mathrm{pH} 3.0$ during 2-5 h.

\section{Preliminary identification of lactic acid bacteria isolates}

Eleven isolates that exhibited potential growth at low $\mathrm{pH}$ and bile salt $2 \%$ were preliminary identified based on their morphological, physiological and biochemical characterization (Table 5). Biochemical characteristics were compared with Bergey`s Manual of Determinative Bacteriology (Holt et al., 1994). All LAB isolates were Gram positive; seven isolates were cocci while four isolates were rods with long and rounded ends. No bubble was observed indicating that the isolated bacteria are catalase negative and could not mediate the decomposition of $\mathrm{H}_{2} \mathrm{O}_{2}$ to produce oxygen. All the isolates were not able to use citrate as the sole source of carbon and energy, negative for $\mathrm{H}_{2} \mathrm{~S}$ production, positive for methyl red test and negative for VP test except isolates MS12, MS24, MS44 and MS71. These are the common characteristics of LAB species. These findings are also similar to those reported by Khagwal1, et al. (2019). 
Table 4. Tolerance of $\mathrm{pH}$ by bacterial isolates.

\begin{tabular}{|c|c|c|c|c|c|c|c|c|c|c|c|c|}
\hline \multirow{2}{*}{$\begin{array}{c}\text { Isolate } \\
\text { No. }\end{array}$} & \multicolumn{4}{|c|}{$\begin{array}{c}\text { Survival rate \% at pH } 1.5 \\
\text { after incubation }(\mathrm{h})\end{array}$} & \multicolumn{4}{|c|}{$\begin{array}{c}\text { Survival rate \% at pH } 3 \\
\text { after incubation (h) }\end{array}$} & \multicolumn{4}{|c|}{$\begin{array}{c}\text { Survival rate } \% \text { at } \mathbf{p H ~} 8 \\
\text { after incubation (h) }\end{array}$} \\
\hline & 2 & 3 & 4 & 5 & 2 & 3 & 4 & 5 & 2 & 3 & 4 & 5 \\
\hline MS 8 & 96.4 & 84.5 & 0.0 & 0.0 & 74.4 & 52 & 0.0 & 0.0 & 0.0 & 0.0 & 0.0 & 0.0 \\
\hline MS 12 & 99.7 & 99.7 & 99.7 & 99.6 & 99.7 & 99.6 & 99.6 & 99.6 & 99.8 & 99.7 & 99.6 & 99.6 \\
\hline MS 13 & 101.7 & 102.2 & 103.0 & 107.7 & 100.4 & 100.7 & 101 & 101.2 & 98.5 & 97.9 & 97.7 & 97.7 \\
\hline MS 17 & 98.7 & 94.3 & 0.0 & 0.0 & 98.9 & 98.0 & 97.3 & 83.0 & 99.3 & 94.0 & 92.9 & 60.0 \\
\hline MS 18 & 92.9 & 91.6 & 83.7 & 67.6 & 100.6 & 101.6 & 101.9 & 102.3 & 105.6 & 105.9 & 106 & 106 \\
\hline MS 19 & 99.4 & 99.4 & 98.4 & 98.2 & 100 & 100.9 & 100.9 & 101.9 & 100.3 & 100.6 & 100.9 & 102.3 \\
\hline MS 24 & 93.8 & 89.2 & 81.5 & 76.5 & 100.2 & 100.5 & 100.6 & 100.6 & 100.1 & 100.2 & 100.4 & 100.5 \\
\hline MS 25 & 100.8 & 101.4 & 101.7 & 101.9 & 100.4 & 101.1 & 101.4 & 101.5 & 100.0 & 100.0 & 100.1 & 100.1 \\
\hline MS 37 & 95.0 & 90.1 & 82.3 & 0.0 & 100.4 & 101.4 & 101.8 & 101.9 & 100.5 & 101.1 & 101.3 & 101.5 \\
\hline MS 44 & 100.7 & 101.1 & 101.5 & 101.8 & 100.0 & 100.0 & 100.2 & 100.3 & 100.2 & 100.3 & 100.4 & 100.5 \\
\hline MS 46 & 100.0 & 100.0 & 99.9 & 99.9 & 100.0 & 99.8 & 99.8 & 99.8 & 100.0 & 100.1 & 100.3 & 100.1 \\
\hline MS 47 & 100.3 & 100.5 & 100.6 & 100.8 & 99.9 & 99.9 & 99.9 & 99.9 & 98.9 & 98.9 & 97.8 & 97.1 \\
\hline MS 54 & 97.0 & 81.5 & 0.0 & 0.0 & 99.4 & 96.9 & 94.1 & 84.2 & 0.0 & 0.0 & 0.0 & 0.0 \\
\hline MS 55 & 99.4 & 98.9 & 98.9 & 98.9 & 100.4 & 100.7 & 100.9 & 101 & 100.4 & 100.9 & 101.4 & 102.8 \\
\hline MS 57 & 0.0 & 0.0 & 0.0 & 0.0 & 100.5 & 100.7 & 101.2 & 101.7 & 0.0 & 0.0 & 0.0 & 0.0 \\
\hline MS 60 & 91.7 & 93.5 & 95.3 & 95.9 & 100.6 & 101.1 & 102.4 & 102.5 & 100.3 & 100.5 & 101 & 101.4 \\
\hline MS 62 & 90.9 & 82.1 & 0.0 & 0.0 & 100.4 & 99.5 & 100.0 & 100.2 & 99.9 & 100.0 & 100.0 & 9.99 \\
\hline MS 64 & 96.7 & 94.5 & 94.2 & 93.7 & 100.1 & 100.3 & 100.5 & 100.5 & 83.6 & 84.6 & 85.1 & 86.1 \\
\hline MS 65 & 101.8 & 102.4 & 102.5 & 103.0 & 100.1 & 100.1 & 100.4 & 100.5 & 99.3 & 97.6 & 96.0 & 93.3 \\
\hline MS 67 & 102.6 & 102.9 & 103.4 & 103.5 & 100.4 & 101.0 & 101.7 & 102.4 & 100.8 & 101.7 & 102.7 & 104.2 \\
\hline MS 68 & 100.0 & 100.0 & 100.0 & 100.0 & 100.0 & 100.0 & 100.0 & 100.0 & 100.0 & 100.0 & 100.0 & 100.0 \\
\hline MS 71 & 100.9 & 101.8 & 102.3 & 104.2 & 100.8 & 101.6 & 102.5 & 102.9 & 99.6 & 99.4 & 99.3 & 99.3 \\
\hline MS 84 & 102.8 & 104.3 & 107.2 & 107.7 & 100.9 & 102.6 & 103.7 & 105.4 & 101.7 & 106.2 & 107.2 & 109.8 \\
\hline MS 85 & 99.8 & 99.7 & 99.7 & 99.7 & 100.4 & 100.6 & 100.7 & 100.8 & 100.3 & 100.4 & 100.6 & 100.6 \\
\hline MS 86 & 99.3 & 98.5 & 97.9 & 97.5 & 100.9 & 102.8 & 104.7 & 105.6 & 100.0 & 100.0 & 100.1 & 100.1 \\
\hline MS 87 & 99.8 & 99.6 & 99.5 & 99.4 & 100.3 & 101.2 & 101.5 & 101.7 & 100.1 & 100.4 & 100.5 & 100.5 \\
\hline MS 88 & 99.9 & 99.8 & 99.7 & 99.5 & 100.0 & 100.0 & 100.0 & 100.0 & 100.1 & 100.5 & 100.8 & 100.9 \\
\hline MS 90 & 0.0 & 0.0 & 0.0 & 0.0 & 100.3 & 100.8 & 100.9 & 101.0 & 100.4 & 100.9 & 100.9 & 101.0 \\
\hline
\end{tabular}

Table 5. Preliminary identification of lactic acid bacteria isolates.

\begin{tabular}{|c|c|c|c|c|c|c|c|c|c|c|c|}
\hline Properties & $\begin{array}{c}\text { MS } \\
12\end{array}$ & $\begin{array}{c}\text { MS } \\
13\end{array}$ & $\begin{array}{c}\text { MS } \\
18\end{array}$ & $\begin{array}{c}\text { MS } \\
19\end{array}$ & $\begin{array}{c}\text { MS } \\
24\end{array}$ & $\begin{array}{c}\text { MS } \\
44\end{array}$ & $\begin{array}{c}\text { MS } \\
71\end{array}$ & $\begin{array}{c}\text { MS } \\
84\end{array}$ & $\begin{array}{c}\text { MS } \\
86\end{array}$ & $\begin{array}{c}\text { MS } \\
87\end{array}$ & $\begin{array}{c}\text { MS } \\
88\end{array}$ \\
\hline $\begin{array}{l}\text { Gram reaction } \\
\text { Morphology }\end{array}$ & $\begin{array}{c}\mathbf{G} \\
\text { cocci }\end{array}$ & $\begin{array}{c}\mathbf{G} \\
\text { cocci }\end{array}$ & $\begin{array}{c}\mathbf{G} \\
\operatorname{rods}\end{array}$ & $\begin{array}{c}\mathbf{G} \\
\text { cocci }\end{array}$ & $\begin{array}{c}\mathbf{G} \\
\text { cocci }\end{array}$ & $\begin{array}{c}\mathbf{G} \\
\text { cocci }\end{array}$ & $\begin{array}{c}\mathbf{G} \\
\text { cocci }\end{array}$ & $\begin{array}{c}\mathbf{G} \\
\text { rods }\end{array}$ & $\begin{array}{c}\mathbf{G} \\
\text { rods }\end{array}$ & $\begin{array}{c}\mathbf{G} \\
\text { cocci }\end{array}$ & $\begin{array}{c}\mathbf{G} \\
\text { rods }\end{array}$ \\
\hline Catalase & - & - & - & - & - & - & - & - & - & - & - \\
\hline Citrate & - & - & - & - & - & - & - & - & - & - & - \\
\hline Methyl red & + & + & + & + & + & + & + & + & + & + & + \\
\hline VP-test & + & - & - & - & + & + & + & - & - & - & - \\
\hline $\begin{array}{l}\mathrm{H}_{2} \mathrm{~S} \text { Production } \\
\text { Acid from: }\end{array}$ & - & - & - & - & - & - & - & - & - & - & - \\
\hline -Galactose & ++ & + & + & ++ & + & - & - & - & + & + & + \\
\hline -Xylose & ++ & ++ & + & + & - & - & + & - & - & + & + \\
\hline -Arabinose & + & - & - & ++ & - & - & - & - & - & ++ & - \\
\hline -Sucrose & ++ & ++ & ++ & + & + & + & - & - & + & - & + \\
\hline -Glucose & + & + & + & + & + & + & + & + & + & + & + \\
\hline -Sorbose & ++ & - & - & + & ++ & - & - & - & + & + & - \\
\hline -Lactose & + & + & + & + & + & - & - & + & + & + & + \\
\hline -Mannitol & + & + & + & + & + & + & + & + & + & + & + \\
\hline -Sorbitol & + & + & + & + & - & + & + & - & - & + & + \\
\hline Growth at: & & & & & & & & & & & \\
\hline $\mathrm{pH} 4.5$ & + & + & + & + & + & + & + & + & + & + & + \\
\hline pH 7.6 & + & + & + & + & + & + & + & + & + & + & + \\
\hline pH 9.6 & + & + & + & - & + & + & + & + & + & + & + \\
\hline
\end{tabular}




\section{$\mathrm{NaCl}$ tolerance}

Salt tolerance was done in Table (6). The current results showed that $\mathrm{LAB}$ isolates were able to tolerate all tested concentrations of $\mathrm{NaCl}$ and good growth was observed at $1.5-3.0 \% \mathrm{NaCl}$ with some differences as the growth was decreased when concentration of $\mathrm{NaCl}$ was increased from 3.0 to $7.0 \%$. On the contrary, at $5.0 \% \mathrm{NaCl}$, only 4 isolates (MS84, MS86, MS87 and MS88) showed a highly growth. LAB group need of salt for growth at concentrations of moderately and extremely halophilic (5-30\%). Each genus of LAB has different tolerances to grow on media with different concentrations of $\mathrm{NaCl}$ salt (Vos, et al., 2009). $\mathrm{NaCl}$ is an inhibitory substance which may inhibit growth of certain types of bacteria. The obtained results have the similarities with the findings of Reale, et al. (2015). They reported that lactobacilli isolated from gastrointestinal tract of swine were tolerable to $4-8 \%$ $\mathrm{NaCl}$.

\section{Antioxidant activity}

DPPH, a relatively stable organic radical has been widely used in the determination of antioxidant activities of cell free extracts of bacteria. To elucidate the antioxidant activity of the 11 strains, the scavenging ability of the cell free extracts of LAB isolates were compared with the standard antioxidant ascorbic acid .The DPPH radical scavenging activities of culture filtrate of the $11 \mathrm{LAB}$ isolates were near and over $50 \%$ (Table 6). The maximum antioxidant activity was observed with MS88 showing $75.74 \%$ followed by MS13 with $75.69 \%$. On the other hand, MS12 and MS24 showed antioxidant activity of 74.94 and $72.33 \%$, respectively. Additionally, the culture supernatant had $50 \%$ antioxidant activity as nonpurified solution, demonstrating potential as a natural antioxidant. Increase of the antioxidant capacity by optimizing the environmental factors makes it possible to obtain useful industrial materials. Yang $\boldsymbol{e t}$ al. (2014) reported that there is a significant positive correlation among the antioxidant activities and the metabolite of LAB. It is considered that purification of the filtrate could exhibit a higher activity. This study provides support for the formulation of novel probiotic foods or supplements that can play a role in the prevention of oxidative stress and related diseases.

Table 6. $\mathrm{NaCl}$ tolerance, and antioxidant activity by the LAB isolates

\begin{tabular}{cccccccc}
\hline \multirow{2}{*}{ LAB isolates } & \multicolumn{3}{c}{ NaCl tolerance at concentration $(\boldsymbol{\%})$} & \multicolumn{3}{c}{$\begin{array}{c}\text { DPPH } \\
\text { \% }\end{array}$} \\
\cline { 2 - 8 } & $\mathbf{1 . 5}$ & $\mathbf{3}$ & $\mathbf{5}$ & $\mathbf{7}$ & Inhibited & Residual \\
\hline MS 12 & ++ & ++ & + & + & 74.94 & 25.06 \\
MS 13 & ++ & ++ & + & + & 75.69 & 24.31 \\
MS 18 & ++ & ++ & + & + & 52.82 & 47.18 \\
MS 19 & ++ & ++ & + & + & 49.15 & 50.85 \\
MS 24 & ++ & ++ & + & + & 72.33 & 27.67 \\
MS 44 & ++ & ++ & + & + & 46.37 & 53.63 \\
MS 71 & ++ & ++ & + & + & 64.12 & 35.88 \\
MS 84 & ++ & ++ & ++ & + & 58.47 & 41.53 \\
MS 86 & ++ & ++ & ++ & + & 50.31 & 49.69 \\
MS 87 & ++ & ++ & ++ & + & 47.92 & 52.08 \\
MS 88 & ++ & ++ & ++ & + & 75.74 & 24.26 \\
\hline
\end{tabular}

\section{Hemolytic activity}

The eleven isolates with the best results were tested for their non-pathogenic character by streaking them on blood agar plates (Table7). Tested strains showed no haemolysis ( $\gamma$-haemolysis). Evaluation of haemolytic activity is an important safety requirement frequently used to assess potential probiotic strains. Usually no haemolysis by the test strain is the indicative of its safety for human use (OwusuKwarteng et al., 2015). Absence of haemolytic activity is considered as safety criterion for the selection of a probiotic strain. In our study, none of the selected examined strains exhibited $\alpha$ - or $\beta$ haemolytic activity, when grown in Columbia blood agar, whereas all strains were $\gamma$-haemolytic (no haemolysis). These results are similar with previous observations where all of the tested strains (Pisano, $\boldsymbol{e t}$ al., 2014) or most of them (Argyri, et al., 2013) are $\gamma$ haemolytic.

Table 7. Hemolytic activity of the probiotic isolated LAB.

\begin{tabular}{cccccccc}
\hline Isolates code & \multicolumn{3}{c}{ Hemolytic activity types } & \multicolumn{2}{c}{ Isolates code } & \multicolumn{3}{c}{ Hemolytic activity types } \\
\cline { 2 - 7 } & $\alpha$ & $\beta$ & $\Upsilon$ & & $\alpha$ & $\beta$ & $\Upsilon$ \\
\hline MS12 & - & - & + & MS71 & - & - & + \\
MS13 & - & - & + & MS84 & - & - & + \\
MS18 & - & - & + & MS86 & - & - & + \\
MS19 & - & - & + & MS87 & - & - & + \\
MS24 & - & - & + & MS88 & - & - & + \\
MS44 & - & - & + & & & & \\
\hline
\end{tabular}




\section{Susceptibility of LAB to antibiotics}

The LAB antibiotic susceptibility to different antibiotics is shown in Table (8). Most of the LAB isolates are resistant to many antibiotics. Isolates MS $(12,18,44,84,86,87)$ were resistant to all tested antibiotics while strains MS $(13,24,88)$ were resistant to 5 antibiotics, also, strains MS $(19,71)$ were resistant to 4 antibiotics. Among antibiotic resistances, vancomycin resistance is of major concern because vancomycin is one of the antibiotics broadly efficacious against clinical infections caused by multi drug resistant pathogens. Some LAB including strains MS $(12,18,44,71,84,86,87,88)$ were found to be resistant to vancomycin. Such resistance is usually intrinsic, that is, chromosomally encoded and nontransmissible (Zhou et al., 2000). In addition, results indicated that LAB is resistant to most of antibiotics tested and low multiple susceptible were observed. This result is in accordance with various reports that LAB strains are normally resistant to the principal antibiotics such as chloramphenicol, penicillin $\mathrm{G}$ and vancomycin (Hoque et al., 2010 and Marroki et al., 2011). Innate resistance of probiotics to some antibiotics suggests their use for preventive and therapeutic purposes for controlling intestinal infections especially when co-administered with the therapeutic use of antibiotics (Negm El-Dein, Asmaa et al., 2017).

Table 8. LAB isolates susceptibility to different antibiotics.

\begin{tabular}{cccccccc}
\hline $\begin{array}{c}\text { Isolate } \\
\text { code }\end{array}$ & $\begin{array}{c}\text { PE } \\
(\mathbf{1 0} \boldsymbol{\mu g})\end{array}$ & $\begin{array}{c}\text { NEin } \\
(\mathbf{1 0} \boldsymbol{\mu g})\end{array}$ & $\begin{array}{c}\text { ER } \\
(\mathbf{1 5} \boldsymbol{\mu g})\end{array}$ & $\begin{array}{c}\text { TC } \\
(\mathbf{3 0} \boldsymbol{\mu g})\end{array}$ & $\begin{array}{c}\text { V } \\
(\mathbf{3 0} \boldsymbol{\mu g})\end{array}$ & $\begin{array}{c}\text { CP } \\
(\mathbf{3 0} \boldsymbol{\mu g})\end{array}$ & $\begin{array}{c}\text { G } \\
(\mathbf{1 0} \boldsymbol{\mu g})\end{array}$ \\
\hline MS 12 & $\mathrm{R}$ & $\mathrm{R}$ & $\mathrm{R}$ & $\mathrm{R}$ & $\mathrm{R}$ & $\mathrm{R}$ & $\mathrm{R}$ \\
MS 13 & $\mathrm{R}$ & $\mathrm{R}$ & $\mathrm{S}$ & $\mathrm{R}$ & $\mathrm{R}$ & $\mathrm{R}$ & $\mathrm{S}$ \\
MS 18 & $\mathrm{R}$ & $\mathrm{R}$ & $\mathrm{R}$ & $\mathrm{R}$ & $\mathrm{R}$ & $\mathrm{R}$ & $\mathrm{R}$ \\
MS 19 & $\mathrm{R}$ & $\mathrm{R}$ & $\mathrm{R}$ & $\mathrm{R}$ & $\mathrm{S}$ & $\mathrm{R}$ & $\mathrm{R}$ \\
MS 24 & $\mathrm{R}$ & $\mathrm{R}$ & $\mathrm{R}$ & $\mathrm{R}$ & $\mathrm{S}$ & $\mathrm{R}$ & $\mathrm{R}$ \\
MS 44 & $\mathrm{R}$ & $\mathrm{R}$ & $\mathrm{R}$ & $\mathrm{R}$ & $\mathrm{R}$ & $\mathrm{R}$ & $\mathrm{R}$ \\
MS 71 & $\mathrm{R}$ & $\mathrm{R}$ & $\mathrm{S}$ & $\mathrm{R}$ & $\mathrm{R}$ & $\mathrm{R}$ & $\mathrm{S}$ \\
MS 84 & $\mathrm{R}$ & $\mathrm{R}$ & $\mathrm{R}$ & $\mathrm{R}$ & $\mathrm{R}$ & $\mathrm{R}$ & $\mathrm{R}$ \\
MS 86 & $\mathrm{R}$ & $\mathrm{R}$ & $\mathrm{R}$ & $\mathrm{R}$ & $\mathrm{R}$ & $\mathrm{R}$ & $\mathrm{R}$ \\
MS 87 & $\mathrm{R}$ & $\mathrm{R}$ & $\mathrm{R}$ & $\mathrm{R}$ & $\mathrm{R}$ & $\mathrm{R}$ & $\mathrm{R}$ \\
MS 88 & $\mathrm{S}$ & $\mathrm{R}$ & $\mathrm{R}$ & $\mathrm{R}$ & $\mathrm{R}$ & $\mathrm{R}$ & $\mathrm{R}$ \\
\hline
\end{tabular}

PE: Pencillin G, NE: Neofloxin, ER:Erthromycin, TC:Tetracycline, V: Vancomycin, CP: Chloramphincol, G:Gentamycin. R: resistance, S: sensitive according to Oloyede and Afolabi (2013)

\section{Cholesterol assimilation}

Some of the organism are capable of reducing the cholesterol levels naturally and shows anticholesterol activity. Table (9) shows the results of cholesterol reduction by $\mathrm{LAB}$ isolates in the presence of $0.3 \%$ bile salt. The cholesterol assimilation ranged from $9.79-93.4 \%$. The strains MS (12,18, 19, 44, and
71) had assimilated greater than $70 \%$. Elevated level of certain blood lipids is a greater risk for cardiovascular disease. A few research reports describe the use of $L A B$ to decrease the serum cholesterol levels in human and animals (Lee et al., 1992).

Table 9. Cholesterol assimilation by LAB isolates.

\begin{tabular}{ccc}
\hline LAB isolates & Cholesterol assimilated $(\boldsymbol{\mu g} / \mathbf{m l})$ & Cholesterol assimilated $(\%)$ \\
\hline MS 12 & 783.06 & 93.4 \\
MS 13 & 82.06 & 9.79 \\
MS 18 & 773.86 & 92.3 \\
MS 19 & 728.23 & 86.9 \\
MS 24 & 407.72 & 48.6 \\
MS 44 & 780.85 & 93.2 \\
MS 71 & 604.96 & 72.2 \\
MS 84 & 551.23 & 65.8 \\
MS 86 & 442.86 & 52.8 \\
MS 87 & 426.86 & 50.9 \\
MS 88 & 567.98 & 67.8 \\
\hline
\end{tabular}

Cholesterol assimilated $(\mu \mathrm{g} / \mathrm{ml})$ at zero time $=838.07$ 
There are reports indicated that lactic acid bacteria can reduce the serum cholesterol level up to $50 \%$ in presence of bile salt in $48 \mathrm{~h}$ (Guslandi et al., 2003). It has been reported that the ability of the microorganism to reduce the cholesterol level was due to assimilation of cholesterol within bacterial cell and increased excretion of bile salts due to deconjugation by the bile salt hydrolase (Salminen et al., 2002). Probiotic bacteria are advantageous as they are naturally found in foods such as yoghurt, are inexpensive and are generally regarded as safe (GRAS). Of interest are the recent results demonstrating that probiotic bacteria have significant cholesterol-lowering properties (TomaroDuchesneau et al., 2014). The hypocholesterolemic effects of probiotic bacteria have been linked to intrinsic bile salt hydrolase activity cholesterol assimilation and incorporation in cellular membranes and the production of compounds such as fatty acids, , that can inhibit the activity of enzymes, including HMG-CoA reductase (Kim, et al.,2003).

\section{S rRNA Sequence Analyses}

After the 16S rRNA sequences of the potent LAB (MS87) was edited, consensus sequence obtained was blasted in GenBank of NCBI and showed similarity of $100 \%$ in the GenBank. Accordingly, the phylogenetic tree made from sequenced 16S rRNA region of the bacterial isolate indicated that MS87 isolate was identified and belonging to Pediococcus pentosaceus. (Fig.3).

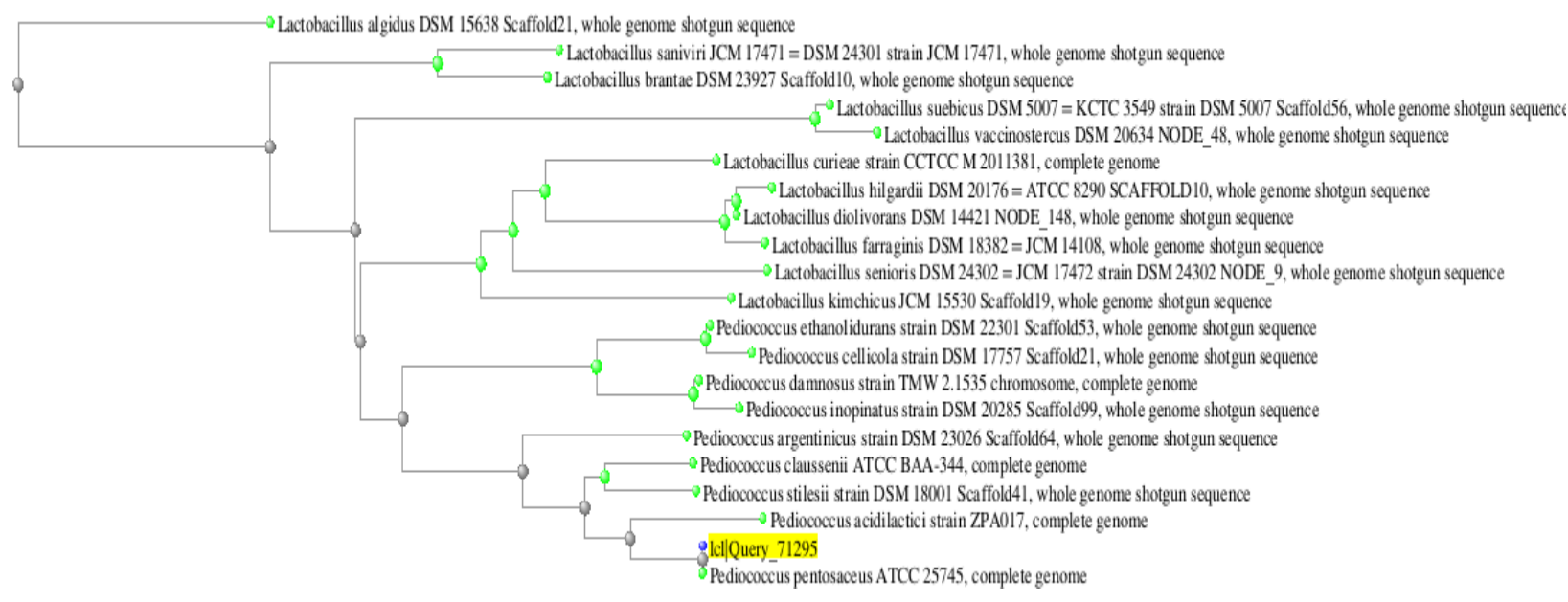

Fig. 3: Phylogenetic tree of nucleotide sequence of LAB isolate MS87

\section{References}

Antara, N. S.; Dibia, I. N. and Aryanta, W.R. (2009). Characterization of Lactic acid bacteria isolated from horse milk of Bima. Agritech., 29(1): 1- 9.

Argyri, A. A.; Zoumpopoulou, G.; Karatzas, K. A. G.; Tsakalidou, E.; Nychas, G. J. E.; Panagou, E. Z. and Tassou, C. C. (2013). Selection of potential probiotic lactic acid bacteria from fermented olives by in vitro tests. Food microbiology, 33(2), 282-291.

Badi, R. and Bhat, M. (2017). Isolation studies of Bacteriocin producing Lactic acid bacteria from raw goat milk. World Journal of Microbiology, 4(1): 093-099.

Bhattacharyya, B. K. (2009). Emergence of probiotics in therapeutic applications. International Journal of Pharmaceutical Sciences and Nanotechnology, 2(1): 383- 389.

Borah, D. ; Gogoi, O.; Adhikari, C. and Kakoti, B. B. (2016). isolation and characterization of the new indigenous Staphylococcus sp. DBOCP06 as a probiotic bacterium from traditionally fermented fish and meat products from Assam state. Egyptian Journal of Basic and Applied Sciences. 3: 232240.

Caggianiello, G. ; Kleerebezem, M. and Spano,G. (2016). Exopolysaccharides produced by lactic acid bacteria: From health-promoting benefits to stress tolerance mechanisms. Appl. Microbiol. Biotech- nol., 100:3877-3886

Chang, Y.C. ; Wang Y.C. , Wang I.K. ; Lin C.F. ; Chuang, H.L. ; Wu, Y.Y. ; Chung, T.C. and Chen, T.H. (2012). Ciprofloxacin and tetracycline susceptibility of lactobacilli isolated from indigenous children's feces. Afr J Microbiol Res., 6: $245-50$.

Collins, J. K. ; Thornton, G. and Sullivanm, G. O. (1998). Selection of probiotic strains for human applications. Int. Dairy J., 8:487- 490.

Daba, H. and Saidi, S. (2015). Detection of bacteriocin-producing lactic acid bacteria from milk in various farms in north-east Algeria by a 
new procedure. Agronomy Research.,13(4): 907918.

De- Man, J.C. ; M. Rogosa and E. Sharpe (1960). Medium of lactobacilli. J. Appl. Bacteriol., 23:130-135.

Doi, K. ; Phuong, A. ; Kawatou, F. ; Nagayoshi, Y. ;Fujino, Y. and Ohshima, T. (2013). Identification and characterization of lactic acid bacteria isolated from fermented rice bran product. Adv. Microbiol., 3: 265-272.

Erkkila, S. and Petaja, E. (2000). Screening of the commercial meat starter cultures at low $\mathrm{pH}$ and in the presence of bile salts for potential use of probiotic use. Meat Sci., 55:297-300.

Fungsin, B. ; Wannissorn, B. ; Chatanon, L. ; Srichuai, A. and Artjariyasripong, S. (2010). Screening of lactic acid bacteria isolated from cow dung for probiotic properties. The $8^{\text {th }}$ International Symposium on Biocontrol and Biotechnology, $4^{\text {th }}$ to $6^{\text {th }}$ October 2010 Pattaya, Chonburi, Thailand.

Gardiner, G. ; Stanton,C. ; Lynch, P.B. ; Collins, J.K. ; Fitzgerald, G. and Ross, R.P. (1999). Evaluation of cheddar cheese as a food carrier for delivery of a probiotic strain to the gastrointestinal tract. J. Dairy Sci., 82:1379-1387.

Guslandi, M. ; Giollo, P. and Testoni, P. A. (2003). A pilot trial of Saccharomyces boulardii in ulcerative colitis. Eur. J. Gastroenterol. Hepatol., 15: 697-698.

Heo, S.J. ; Park, E.J. ; Lewm, K.W. and Jeon, Y.J. (2005). Antioxidant activities of enzyme extracts from brown seaweeds. Bioresource Technol., 96: 1613-1623.

Hirayama, K. and Rafter, J. (2000). The role of probiotic bacteria in cancer prevention. Microb. Infect., 2: 681-686.

Holt, J. G. ; Krieg, N. R. ; Sneath, P. H. A. ; Staley, J. T., and Williams, S. T. (1994). Bergey's Manual of Determinative Bacteriology, 9th edition. Baltimore, M. D. Williams and Wilkins (eds.).

Hoque, M. Z. ; Akter, F. ; Hossain, K. M. ; Rahman, M. S. M. ; Billah, M. M. and Islam, K. M. D. (2010). Isolation, identification and analysis of probiotic properties of Lactobacillus spp. from selective regional yoghurts. World Journal of Dairy and Food Sciences, 5(1):39- 46.

Jiménez, E. ; Fernández, L. ; Maldonado, A. ; Martín, R. ; Olivares, M. ; Xaus, J., and Rodríguez, J. M. (2008). Oral administration of Lactobacillus strains isolated from breast milk as an alternative for the treatment of infectious mastitis during lactation. Appl. Environ. Microbiol., 74(15), 4650-4655.

Kacem, M. and Karam, N. (2006). In vitro preselection criteria for probiotic Lactobacillus plantarum strains of fermented olives origin. International Journal of Probiotics and Prebiotics, 1 (1): 27- 32 .
Khagwal1, N. ; Sharma, D.C. and Sharma P.K. (2019). Isolation and Characterization of Potential Probiotic Strains Isolated from Traditional Indian Fermented Foods. Int. J. Curr. Microbiol. App. Sci., 8(3):680-689.

Kim, H. K. ; Jeong, T.-S. ; Lee, M.K. ; Park, Y. B. and Choi, M.S. (2003). "Lipid-lowering efficacy of hesperetin metabolites in highcholesterol fed rats," Clinica Chimica Acta. 327(1-2): 129-137.

Lawrence, S.J. ; Korzenik, J.R. and Mundy, L.M. (2005). Probiotics for recurrent Clostridium difficile disease. J. Med. Microbiol., 54: 905-906.

Lee, Y.W. ; Roh, W.S. and Kim, J.G. (1992). Benefits of fermented milk in rats fed by hypercholesterolemic diet (II). Korean J. Food Hyg., 7: 123-135

Marroki, A. ; Zuniga, M. ; Kihal, M. and PerezMartinez, G. (2011). Characterization of Lactobacillus from Algerian goat's milk based on phenotypic, 16S rDNA sequencing and their technological properties. Brazilian Journal of Microbiology, 42:158- 171.

Martin, F.P. ; Wang,Y. ; Sprenger, N. ; Yap, I.K. ; Lundstedt, T., Lek, P. ; Rezzi, S. ; Ramadan, Z., van Bladeren, P., Fay, L.B. ; Kochhar, S. ; Lindon, J.C. ; Holmes E. and Nicholson, J.K. (2008). Probiotic modulation of symbiotic gut microbial-host metabolic interactions in a humanized microbiome mouse model. Mol. mode of action. Poul. Sci. 84: 634-643.

Morelli, L. (2000). In vitro selection of probiotic lactobacilli: A critical appraisal. Curr. Issues Oloyede a.r., and Afolabio.r.(2013). Phenotypic characterization and in vitro screening of lactic acid bacteria from goat milk for probiotic use., J. Agric. Sci.\& Env., 13: 50-59

Negm El-Dein, Asmaa , Nour El-Deen, Azza M., Tolba, Sahar M., El-Shatoury, Einas H., Awad, Ghada A. ; Ibrahim,M. K. ; Mohamed A. and Farid, M. A. (2017). Probiotic properties and bile salt hydrolase activity of some isolated lactic acid bacteria. Egypt. J. Micro., 52:87 - 100.

Oloyede A.R. and Afolabio.R. (2013). Phenotypic characterization and in vitro screening of lactic acid bacteria from goat milk for probiotic use., J. Agric. Sci. and Env., 13: 50-59.

Owusu-Kwarteng, J. A. M. E. S. (2013). Molecular diversity and technological properties of predominant microorganisms associated with the processing of millet into fura, a fermented food in Ghana (Doctoral dissertation, University of Ghana).

Pisano, M. B. ; Viale, S. ; Conti, S. ; Fadda, M. E., Deplano, M. ; Melis, M. P. and Cosentino, S. (2014). Preliminary evaluation of probiotic properties of Lactobacillus strains isolated from Sardinian dairy products. BioMed research international, 2014.

Reale, A. ; di Renzo, T. ; Rossi, F. ; Zotta, T. and Iacumin, L. (2015). Tolerance of Lactobacillus 
casei, Lactobacillus paracaseiand and Lactobacillus rhamnosus strains to stress factors encountered in food processing and in the gastrointestinaltract. LWT-Food Sci. Technol., 60: 721728.

Salminen, M.K. ; Tynkkynen, S., Rautelin, H., Saxelin, M., Vaara, M., Ruutu, P. ; Sarna, S. ; Valtonen, V. and Jarvinen, A., (2002). Lactobacillus bacteremia durin a rapid increase in probiotic use of Lactobacillus rhamnosus GG in Finland. Clin. Infect. Dis., 35: 1155-1160.

Searcy, R.L. and L.M. Bergquist, (1960). A new color reaction for the quantification of serum cholesterol. Clin. Chim. Acta, 5: 192-199.

Sedláčkovám, P. ; Horáčková, Š. ; Shi, T. ; Kosovám, M. and Plocková, M. (2015). Two different methods for screening of bile salt hydrolase activity in Lactobacillus strains. Czech J. Food Sci., 33: 13-18.

Somashekaraiah, R. ; Shruthi, B. ; Deepthi, B. V. and Sreenivasa, M. Y. (2019). Probiotic properties of lactic acid bacteria isolated from Neera: A naturally fermenting coconut palm nectar. Frontiers in Microbiology, 10:1382-1392.

Tannock, G. W. (1995). Microecology of the gastrointestinal tract in relation to lactic acid bacteria. Int. Dairy J. 5: 1059-1070.

Tomaro-Duchesneau, C. ; Saha, S. ; Malhotra, M. et al., (2014). "Effect of orally administered $\boldsymbol{L}$. fermentum NCIMB 5221 on markers of metabolic syndrome: an in vivo analysis using ZDF rats," Applied Microbiology and Biotechnology, 98, pp. 115-126.

Toit, D. M. ; Dicks, L.M.T. and Holzapfe, W.H. (2003). Identification of heterofermentative lactobacilli isolated from pig faeces by numerical analysis of total soluble cell protein patterns and RAPD-PCR. Lett. Appl. Microbiol., 37:12-16.
Verdenelli, M. ; Ghelfi, F. ; Silvi, S. ; Orpianesi, C. ; Cecchini, C. and Cresci. A. (2009). Probiotic properties of Lactobacillus rhamnosus and Lactobacillus paracasei isolated from human faeces. Eur. J. Nut., 48: 355-363

Vieco-Saiz, N., Belguesmia, Y., Raspoet, R., Auclair, E., Gancel, F., Kempf, I., and Drider, D.(2019). Benefits and inputs from lactic acid bacteria and their bacteriocins as alternatives to antibiotic growth promoters during food-animal production. Frontiers in Microbiology, 10:57-73.

Vos, D.P. ; Garrity, G.M. ; Jones, D. ; Krieg, N.R. ; Ludwig, W. ; Rainey, F.A. ; Schleifer, K.H. and Whitman, W.B (2009). Bergey`s Manual of Systematic Bacteriology. Springer Dordrecht Heidelberg. New York, USA.

Weese, J. S. ; Weese, H. E. ; Yuricek, L. and Rousseau, J. (2004). Oxalate degradation by intestinal lactic acid bacteria in dogs and cats. Vet. Microbiol., 101(3): 161-166

Yang, H.S. ; Choi, Y.J. ; Oh, H.H. ; Moon, J.S. ; Jung, H.K. and Kim, K.J. (2014). Antioxidative activity of ushroom water extracts fermented by lactic acid bacteria. J. Kor. Soc. Food Sci. Nutr., 43: 80-85.

Yin, Q. and Zheng, Q. (2005). Isolation and identification of the dominant Lactobacillus in gut and feces of pig using carbohydrate fermentation and 16S rDNA analysis. J. Biosci. Bioeng., 99: $68-67$.

Zhou, J.S. ; Shu, Q. ; Rutherfurd, K.J. ; Prasad, J. ; Birtles, P.K. ; Gopal, M. and Gill, H.S. (2000). Safety assessment of potential probiotic lactic acid bacterial strains Lactobacillus rhamnosus HN001, Lb. acidophilus HN017, and Bifidobacterium lactis HN019 in BALB/c mice. Int. J. Food Microbiol., 56: 87-96. 